\title{
Fecundity of the crustacean Mysidopsis californica (Mysida, Mysidae) under semi-controlled conditions
}

\author{
Armando A. Ortega-Salas, Arturo Núñez-Pastén \& Humberto A. Camacho M. \\ Instituto de Ciencias del Mar y Limnología, Unidad Académica Mazatlán, Calzada Joel M., Camarena s/n. Playa Sur, \\ Código postal 82040, Apdo. post: 811, Mazatlán, Sinaloa, México; ortsal@ola.icmyl.unam.mx
}

Received 19-III-2007. Corrected 20-XI-2007. Accepted 28-IV-2008.

\begin{abstract}
Mysid crustaceans are frequently used in the laboratory to feed cephalopods and fish, but not along the Pacific coast, where they are scarce. There is no commercial aquaculture of mysids in the Pacific Ocean. To change this situation, we calculate fecundity, survival, and sex ratio of Mysidopsis californica under semi-controlled conditions. Mysids were collected manually using a $500 \mu \mathrm{m}$-mesh net along the rocky coast of Mazatlán, Sinaloa, Mexico. They were transferred to three $30 \mathrm{~L}$ seawater aquaria in the laboratory, and fed (ad libitum) Artemia nauplii and rotifers. Two generations were obtained. The relationship between the number of juveniles born and parent female lengths showed a rate of 1.56 juveniles released per each unit of increasing parent female length. An average parent female length of $6.92 \mathrm{~mm}(\mathrm{SD}=0.82)$ gave $9.96(\mathrm{SD}=4.29)$ released juveniles. The frequency of female length showed a mean of $7.3 \mathrm{~mm}(\mathrm{SD}=0.54)$, whereas that of juveniles showed a mean of $1.7 \mathrm{~mm}(\mathrm{SD}=0.16$ ). Survival and sex ratios (females-males) varied from $77.7 \%$ to $88.6 \%$ and $2.5: 1$ to $3.0: 1$, respectively. Rev. Biol. Trop. 56 (2): 535-539. Epub 2008 June 30.
\end{abstract}

Key words: Mysidopsis californica (Mysida, Mysidae), fecundity, survival, sex ratio, Mexican Pacific Ocean.

A distinguishing characteristic of mysids is their broad pouch or ventral marsupium in mature females, where the embryos develop directly into juveniles, possessing many adult characters. Wortham-Neal and Price (2001) studied the marsupial developmental stages in Americamysis bahia (Mysida: Mysidae and Lophogastridae). Most shallow waters mysids measure between 2 and $30 \mathrm{~mm}$ in length, but some bathypelagic species such as Gnathophausia, grow up to $35 \mathrm{~cm}$. Most mysids are omnivorous.

In the natural environment, mysids often congregate in large groups and constitute the diet of many large marine organisms (Ruppert and Barnes 1996). Hence, mysids are frequently used in the laboratory to feed juveniles of cephalopods (Clarke et al. 1989, Hanlon et al. 1991, Dominguez et al. 2004) as well as fish (Woods 2005, Foster et al. 2001, Reicher 2003).

Mysids along the Pacific coast are scarce and as a consequence are rarely used as a food source in the laboratory. There is no commercial aquaculture of mysids in the Pacific Ocean. Therefore the purpose of this study is to estimate fecundity, frequency of reproduction, survival, and sex ratio of Mysidopsis californica under semi-controlled conditions, these results may help in planning mass culture of mysids for feeding some laboratory raised and maintained marine specimens.

\section{MATERIALS AND METHODS}

Mysids were collected manually using a $500 \mu \mathrm{m}$-mesh net in the Mazatlán Bay along 
the rocky coast of Mazatlán, Sinaloa (Mexico) on February 10, 2003 and January 15, 2004. They were transferred to three $30 \mathrm{~L}$ seawater aquaria in the laboratory, and fed (ad libitum) Artemia nauplii and rotifers. From these, 406 brooding females were selected and placed individually in $150 \mathrm{ml}$ plastic containers and fed Artemia nauplii. The juveniles of each female were counted and measured as they dropped from the marsupia of females. From January 15th sampling, 250 juveniles were settled in three $2 \mathrm{~L}$ flasks. Two generations were obtained to register the time of marsupium development and release of juveniles; from the second generation 36 juveniles were settled likewise to obtain the same parameters. Released juveniles by females were counted. Survival was also calculated. The adult's sex ratio of reproductively active mysids was also calculated in three occasions in January 15th 2004 sampling settled in the $30 \mathrm{~L}$ aquaria.

\section{RESULTS}

Table 1 shows that from 250 juveniles settled in three 2 L flasks on 16th february, a mature marsupium appeared between March 1 to 5 (13-17 days), then they released the brood 6-7 days later (March 13) of the first generation, the parents showed a survival rate of 88
$\%$, at a range temperature between 20.5 and $21.2{ }^{\circ} \mathrm{C}$, and salinity of $35 \%$ oo. From these, 36 juveniles of the second generation were moved to other three $2 \mathrm{~L}$ flasks on 15th March. In these juveniles a mature marsupium appeared in about 12 days (March 27), then they released the brood in about six days (April 2), the parents showed a survival rate of $77.7 \%$, at a temperature range of 21.6 to $23.3{ }^{\circ} \mathrm{C}$, and salinity of $34 \%$. An average female length of $6.96 \mathrm{~mm}(\mathrm{SD}=0.82)$ released $9.96(\mathrm{SD}=4.29)$ juveniles. The females-males ratio varied from 2.5:1 to 3.0:1. They were fed with Artemia nauplii and rotifers (ad libitum).

Fig. 1 depicts the relationship between the number of released juveniles and the maternal lengths, revealing a low correlation $(\mathrm{r}=0.27$, $\mathrm{p}=0.1969$ ), which is not significant. Although relationship shows that 1.56 juveniles are released per unit of length increase. Four hundred and six female parents yielded a mean length of $7.1 \mathrm{~mm}(\mathrm{SD}=0.54)$ and a mean juveniles release of 10.3 ( $\mathrm{SD}=3.15)$. Fig. 2 depicts the length frequency histogram of females and juveniles revealing a mean of $7.3 \mathrm{~mm}$ $(\mathrm{SD}=0.54)$ and a mean of $1.7 \mathrm{~mm}(\mathrm{SD}=0.16)$, respectively.

The information obtained from this study may be helpful in planning mass cultures of mysids for feeding some laboratory raised and maintained marine specimens.

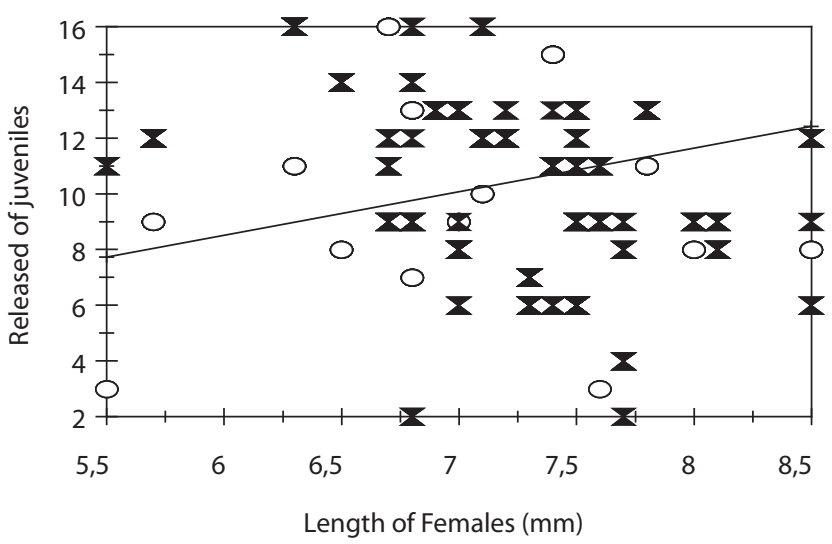

Fig. 1. Relationship between females length with juveniles released. $\mathbf{X}$ data are from the year 2003, and 0 data are from the year 2004. Juveniles released $=$ 40-4.16 (Females length) $n=406, r=0.27$. 
TABLE 1

First and second generations of mysids born under semi-controlled conditions of temperature and salinity

1st Generation

Initial

Flask 1 \# org.

Flask 2 \# org.

Flask 3 \# org.

Total org.

Temperature

Salinity

16 feb $04 *$

83

83

84

250

20,5

35

Final / released

13 Mar. 04

73

74

73

220

21,2

35,1

Surviving

$88 \%$

$89 \%$

$89 \%$

$88 \%$

2nd Generation

Initial

Flask1 \# org.

Flask2 \# org.

Flask3 \# org.

Total org.

Temperature

Salinity

15 March 04 **

12

12

12

36

21,6

34

Final / released

\section{Apr 04}

9

9

28

23,3

34

Surviving

$75 \%$

$83,30 \%$

$75 \%$

$77,70 \%$

Relation females:males

$\begin{array}{lccccc} & & \text { Females } & \text { Males } & \text { Total } & \text { females:males } \\ 1^{\text {st }} \text { Exp. } & 18 \text { march } 04 & 102 & 34 & 136 & 3.0: 1.0 \\ 2^{\text {nd }} \text { Exp. } & 20 \text { march } 04 & 175 & 71 & 246 & 2.5: 1 \\ 3^{\text {th }} \text { Exp. } & 22 \text { march } 04 & 79 & 30 & 109 & 2.6: 1\end{array}$

Mean released juveniles by fema 1 es length

Females length $7.1 \mathrm{~mm}$

Released juveniles 10.3

* Marsupium development march $1^{\text {st }}-5^{\text {th }}$

** Marsupium development march $27^{\text {th }}$

\section{DISCUSSION}

Wittmann (1984) found that temperature is an important environmental factor for marsupial development. Many species of mysids have an incubation period between eight and 180 days at temperatures between $3{ }^{\circ} \mathrm{C}$ and $23{ }^{\circ} \mathrm{C}$, respectively. In this study the temperature varied from 20.5 to $23.3{ }^{\circ} \mathrm{C}$. In Mazatlán Bay the marsupium developed well, but at higher temperatures is difficult to find $M$. californica.

The number of embryos among different species varies: Bowmaniella floridiana yielded between 2 and 55 embryos per each 

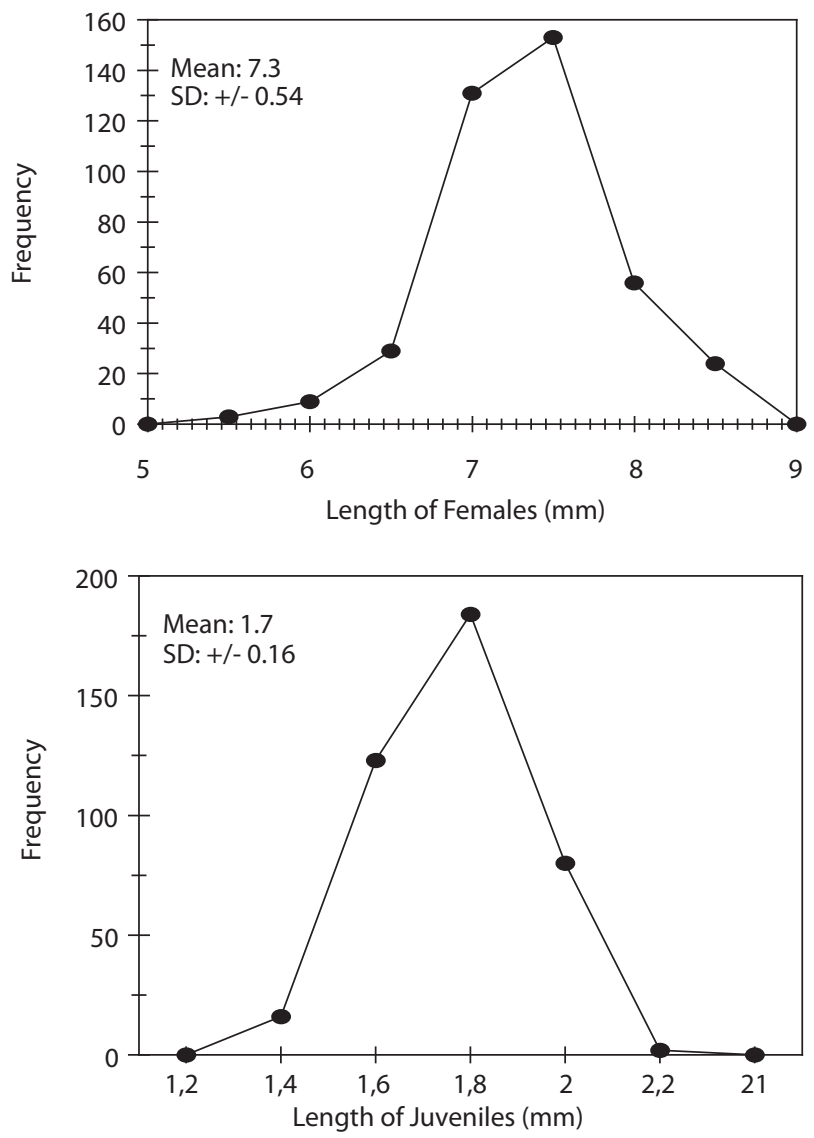

Fig. 2. Frequency of adult female's length, and juveniles length.

mature female, Eucopia unguiculata (E. hanseni) between 8 and 23 embryos (Casanova 1977), and Metamysidopsis swifti between 3 and 42 embryos (Clutter 1967). Mauchline (1973a, 1973b) found that brooding females of Pranus inermis of 13 and $15 \mathrm{~mm}$ length produce between 7 and 32 embryos, respectively. The same author (1973b) found also that, in 133 mysids species, the female length varied between 1.8 and $145 \mathrm{~mm}$, the number of brood was between 1 and 245 and the eggs diameter was between 0.2 and $4 \mathrm{~mm}$. This study shows that females between 5.5 to $8.5 \mathrm{~mm}$ produced between 2 to 16 juveniles; an average female length of $7 \mathrm{~mm}$ produced an average brood of 10 juveniles.
Mauchline (1973a) and Wittmann (1981) calculated a mortality rate of $10 \%$ during development of embryos in the wild due to premature expulsion from the marsupium. The mortality rate included cannibalism and the effect of parasite isopods. The present study revealed a mortality rate between 12 and $23 \%$, at temperatures between 20.5 and $23.3{ }^{\circ} \mathrm{C}$, respectively.

The results of this study provide data that can be useful for aquaculture of this mysid species as a food source for fish larvae and crustaceans kept in the laboratory. Regarding culture of $M$. californica, it is important to have enough live Artemia as food, temperatures around $20 \pm 2{ }^{\circ} \mathrm{C}$, to clean the daily debris, and to provide adequate aeration. 


\section{ACKNOWLEDGMENTS}

We thank S. Rendón R. and C. Ramírez J. for their technical assistance.

\section{RESUMEN}

El objetivo de este trabajo fue calcular la fecundidad, supervivencia y la proporción de sexos de Mysidopsis californica en condiciones semi-controladas. Los animales fueron recolectados manualmente utilizando una red con malla de $500 \mu \mathrm{m}$ a lo largo de la costa rocosa de Mazatlán, Sinaloa, México. Una vez en el laboratorio fueron colocados en tres acuarios de $30 \mathrm{~L}$ cada uno y alimentados con nauplios de Artemia y rotíferos; estudiándose dos generaciones. La relación entre el número de jóvenes nacidos y la longitud de las madres dio una tasa de 1.56 jóvenes nacidos por cada unidad de incremento de la longitud de la hembra. En promedio, hembras de $6.92 \mathrm{~mm}(\mathrm{SD}=0.82)$ producían $9.96(\mathrm{SD}=4.29)$ jóvenes. La frecuencia de la longitud promedio de la hembra fue de $7.3 \mathrm{~mm}(\mathrm{SD}=0.54)$, mientras que los jóvenes medían en promedio $1.7 \mathrm{~mm}(\mathrm{SD}=0.16)$. La supervivencia y la proporción de sexos (hembrasmachos) varió entre $77.7 \%$ y $88.6 \%$ y entre $2.5: 1$ y $3.0: 1$, respectivamente.

Palabras clave: Mysidopsis californica (Mysida, Mysidae), fecundidad, supervivencia, proporción de sexos, Océano Pacifico Mexicano.

\section{REFERENCES}

Casanova, J.P. 1977. La faune pelagique profonde (zooplancton et micronecton) de la province AtlantaMediterranéenne. Aspects taxonomique, biologique et zoogeographique. Doctoral dissertation, degree in Natural Sciences, Université de Provence, Marseille, France.

Clutter, R.I. 1967. Zonation of near shore mysids. Ecology 48: 200-208.
Domingues, P., A. Sykes, A. Sommerfield, E. Almansa, A. Lorenzo \& J.P. Andrade. 2004. Growth and survival of cuttlefish (Sepia officinalis) of different ages fed crustaceans and fish. Effects of frozen and live prey. Aquaculture 229: 239-254.

Foster, E.G., D.A. Ritz, J.E. Osborn \& K.M. Swading. 2001. Schooling affects the feeding success of Australian salmon Arripis trutta when preying on mysid swarms Paramesopodopsis rufa. J. Exper. Mar. Biol. Ecol. 261: 93-106.

Hanlon, R.T., P.E. Turk \& P.G. Lee. 1991. Squid and cuttlefish mariculture: an update perspective. J. Cephal. Biol. 2: 31-40.

Mauchline, J. 1973a. The broods of British Mysidacea (Crustacea). J. Mar. Biol. Assoc. U. K. 53: 801-817.

Mauchline, J. 1973b. The broods of British Mysidacea (Crustacea). J. Mar. Biol. Assoc. U. K. 53: 569-572.

Reichert, M.J.M. 2003. Diet, consumption, and growth of juvenile fringed flounder (Etropus crossotus): a test of the 'maximum growth/optimum food hypotheses in a subtropical nursery area. J. Sea Res. 50: 97-116.

Ruppert, E \& R. Barnes. 1996. Zoología de los Invertebrados. McGraw-Hill Interamericana, México D.F., México.

Wittmann, K.J. 1981. On the breeding biology and physiology of marsupial development in Mediterranean Leptomysis (Mysidacea: Crustacea) with special reference to the effects of temperature and egg size. J. Exper. Mar. Biol. Ecol. 53: 261-279.

Wittmann, K.J. 1984. Ecophysiology of marsupial development and reproduction in Mysidacea (Crustacea). Ocean. Mar. Biol. Ann. Rev. 22: 393-428.

Woods, C.M.C. 2005. Growth of cultured seahorses (Hippocampus abdominalis) in relation to feed ration. Aquacult. Internat. 13: 305-314.

Wortham-Neal, J.L. \& W.W. Price. 2001. Marsupial developmental stages in Americamysis bahia (Mysida: Mysidae). J. Crust. Biol. 22: 98-112. 